\title{
AMBIANTAL ARCHITECTURE - Defining the role of water in the aesthetic experience of sensitive architectural ambiances
}

\author{
Gregory Brais Sioui ${ }^{1}$ \\ ${ }^{1}$ Laval University, Architecture school, Québec, QC, Canada
}

\begin{abstract}
As part of an aesthetic approach, this design-driven research crosses two methodologies to determine what is common in the perception of atmospheres. First, a case study of the Vals' thermal baths led to the selection of five different atmospheres, which were then analyzed through Gaston Bachelard's lens, using his book L'Eau et les rêves. Bachelard's literary symbols echo in the water contained in the massive stone walls of Vals to identify common generators of sensitive atmospheres. Secondly, the construction of this dialogue between Bachelard and Zumthor leads to the elaboration of a conceptual architecture project which is voluntarily emotional. This project introduces the elements that generate five ambiences identified in the case study. This design-driven research is therefore based on Grégoire Chelkoff's theory of formants as vectors of transmission of atmosphere, pre-existing to the experienc of a place, of an ambiance, which itself is understood as a sensitive result of the perception of the space. The present work therefore questions the role of water as a sensitive vector, from the architecture to its visitor. The goal is to determine how water, in varying manifestations, can be used by architects to create a "mise en scène" for a voluntarily emotional architecture.
\end{abstract}

\section{Architecture as art}

Between artisans and artists, architects use the material and immaterial realms to set the scènes of reality, to set the backdrop of people's lives. Seen as the first art, architecture carries within it the potential to produce emotion: Le Corbusier said, "construction is made to hold, architecture, to move." 1 The individuality behind an emotive response to an environment makes it impossible and undesirable to establish an architectural recipe that would lead to a specific emotion. However, it's still possible and desirable to produce "an [architecture] work with emotion as a function"1. This goal was aimed at by Mathias Goeritz when conceiving the El Eco experimental museum. Not so much about generating a definite architecture which would produce a single predetermined emotion, the goal here is rather to offer various opportunities that might move a variety of visitors.

\footnotetext{
${ }^{1}$ Cited in: N. Gilsoul. "L’architecture émotionnelle, cadrage conceptuel." Chap. 1 In Architecture émotionnelle : matière à penser, pp.37-73. [Lormont]: Le Bord de l'Eau, (2011).
} 
It's in this context of inherence between architecture and art that this work questions what is common in the perception of certain architectural atmospheres. The development of this thesis is constructed in two interdependent parts, the first building the second: a case study will lead to a conceptual architectural design exercise, with both parts to be interpreted through the same theoretical framework. Mainly, the objective of this work is to propose a creative approach based on the conclusions of an analysis that crosses a philosophical work and an architectural work, together generating a design-driven research.

More specifically, the aim is to define generic generators of atmosphere from different rooms of the Vals thermal baths, a project carried out by Peter Zumthor in 1996, by using the book L'Eau et les rêves by Gaston Bachelard, first published in 1942. The analysis then allows to produce an architectural project where emotion becomes a programmatic consideration, by staging and applying these generators of atmosphere in scotch tasting pavilions; it is, in other words, a matter of analyzing a contextual aesthetic appreciation in order to use it to nourish the production of an architectural design project. This design-driven research uses Gregoire Chelkoff's notion of "formant" as a common vector of transition from the atmosphere to the ambiance in a north-western cultural context.

\section{Concepts' definitions}

Four main concepts frame the ideational scheme underlying the reflection addressed in the two portions of this design-driven research. Aesthetics, emotional architecture, sensitive ambiance, and water constitute the themes discussed in this section.

\subsection{The place of beauty}

Etymologically, aesthetics, from the Greek word "aisthēsis" is defined as that which can be perceived by the senses. Since then, this definition has evolved to mean generally, in philosophy, a field studying the perception of nature and art (which includes architecture) regarding the emotions they evoke. The aesthetic experience is no longer an object-centered result perceived in a distant or outsider manner, but rather a multi-sensitive perceptive engagement with its source. In other words, architecture, as an object of art, has gone from an exterior object - to be contemplated - to an intrinsic one - to be lived. One's experience is therefore more engaging.

According to Arnold Berleant's article Aesthetic Sensibility ${ }^{[1]}$, aesthetics is a theory of emotions defined by a developed, guided, focused and trained perceptual awareness. To evaluate the aesthetic functioning of an object, it must pass through the "aesthetic judgement" which is based on the combination of the "aesthetic appreciation" - the perceptive process and the "cultivated sensibility" - the past experience and the knowledge that comes from it. Sonja Schürger echoes this point: "it is important to be aware of the potential indicator of hidden intentions." ${ }^{[2]}$ According to her, the recurrence of this conscious action helps to develop a complexity in the perception of "ambiances' interactions".

\subsection{To move, a goal for... architecture?}

Even if the functionalist approach to architecture, which motored the modern movement, prevailed in its time, it was not universally accepted. It's in the after-war context that the German sculptor Mathias Goeritz, established in Mexico since the late forties, came with the idea of a perception and a feeling-oriented sensitive architecture: the emotional architecture. Proposed by the artist as a reaction to functionalism, which he considered dehumanizing, this concept became, for his friend and colleague Luis Barragàn and himself, an important 
consideration in their respective work. It then further evolved from a consideration to a fullblown conceptual approach, gaining popularity in Mexico. For Goeritz, the idea of an emotional architecture was defined as "a work of art whose main function is to provoke a "maximal emotion" ${ }^{2}$ capable of transcending the modern socity"[3].

As a result, the production of an emotional architecture aims at the composition of a sensitive space which translates conceptual intentions such as the targeted atmosphere. The goal here is to make the visitor part of the architecture by involving them emotionally in it, because it includes a participatory dimension in its experience of space: "the aesthetic appreciation". Thus, the environment acts like a "receptacle of emotions.[...] The sensitive world becomes tangible and the space tunes with lived moments and feelings." ${ }^{[4]}$

\subsection{The atmosphere precedes the experience}

Atmosphere and ambiance are inherent terms. In architecture, they both share a notion of perception of space. Nevertheless, they don't have the same meaning. In order to separate them, here is a proposition for a definition which focuses on the border between those words' meaning. The atmosphere is the result of the work of an architect. With one's art, one can set up the conditions for the existence of an atmosphere. However, it precedes the experience. On the other hand, the ambiance is the result of a lived experience. The atmosphere is not self-sufficient, since an observer must experience it and therefore be in action in the atmospheric space in order for it to materialize into an ambiance - through the observer's perception.

The user experiences an atmosphere with all their senses. Its perception is multi-sensory. Reflecting a spirit-matter relationship, the ambiance is incorporated and embodied in the spatial dispositions, according to one's actions. A link is created between "the physical arrangement of an environment and our way of engaging ourselves within it"[5]. This condition makes the perception of an architectural atmosphere an "active or creative aesthetic experience" [6]. The ambiance is the lived result of these aesthetic experiences. For Gernot Böhme ${ }^{[7]}$, it is defined by its "character". In other words, the way it affects our emotions.

Since "everyone reacts according to one's sensitivity, life experiences, sociocultural prerequisites, the performance of one's sensory receptors and the creativity of one's brain" ${ }^{[8]}$, the ambiance is relative to each observer that experienced it. In consequence, there are as many ambiances as there are observers. Nevertheless, there is a certain uniformity in the perception, a common ambiental context. Thus, without speaking of universality, there is a collective part in the perception of an ambiance. Preconceptions arising from socio-cultural belonging form or distort the perception of a group of individuals. From the singular to the plural, the ambiance inscribed in a social context must be considered as an "inter-individual" experience ${ }^{[9]}$. Arnold Berleant ${ }^{[1]}$ considers changes in movement and period in art as fundamental changes in the sensitivity of a community. This sensitivity is certainly a personal matter, since it derives from memories, experiences, etc., but also from culture. As a result, it includes a part of the collectivity that makes it "inter-individual"[9].

Despite the uniqueness of the ambiance, it is still possible for the architect to influence the aesthetic experience and offer common opportunities to a variety of users. It is through the "mise en scène" that the architect will provide the necessary elements for the emergence of the ambiance.

\footnotetext{
${ }^{2}$ Originally cited in the text as: Mathias Goeritz. Manifesto de la arquitectura emocional, (1954)
} 


\subsubsection{The "mise en scène"}

Scenographing "an ambiance is therefore equivalent to setting the conditions for its appropriation"[7]. For Gernot Böhme, the experience of architectural "scenic space" is "an intermediary between the subject[the observer] and the object[the architecture]"[13]. In order to study this experience, he proposes two approaches: the subject and the object. The subject approach is concerns with the aesthetic of reception, or the study of the sensitive effects of the aesthetic appreciation of ambiances. The object approach explores the aesthetic production: scenography, or rationalizing the ambiance because of the necessity to use "generators" of ambiences. It is this second approach that leads to the exploration of the available tools for the architect to move the visitors.

\subsubsection{The "formants"}

When questioning the perceivable qualities, transcendent the aesthetic object and its aesthetic appreciation, previously broached with Arnold Berleant, it resonates in both Gernot Böhme's and Grégoire Chelkoff's theories. First, Böhme argues that "[ambiance] production is not linked to the determination of objects, but to the way in which they irradiate space to serve as generators of ambiance"[7]. Then Chelkoff describes the ambiance as the lived phenomenon of a "sensitive network" woven between the environment and the user ${ }^{[2]}$. This brief definition lays the foundations of his theory parallel to Böhme's generators: the "formants". He first agrees that architecture is a manifestation of objects entering in relation in space. Through the perception of objects and spaces affecting various sensory registers, some tensions form a sensitive network between the multi-sensory sensitive being and the architectural space. As a result, the terms object and space give way to a representation of sensitive phenomena that he calls "formants". Natural or anthropogenic, tangible or intangible, these elements generate an interaction through time between the element that constitutes it and the sensory event it causes: "the aesthetic appreciation" ${ }^{[1]}$. The "formant" questioned by the present design-driven research is the material image of water.

\subsection{The oneiric power of water}

Water is an archetype of dichotomy. It is simultaneously a source of life, purity, freshness, inspiration, calming and meditation, as well as of strangeness, mysteries, unforeseen events, fears, vices and dangers. Water is at the same time matter, material and materiality in architecture. This tryptic of water falls in Chelkoff's categories to analyze an ambiance: "form, "formant" and formality" [5] respectively material, materiality and matter. These three characteristics of water would be as many considerations in the formation of a deliberately emotional architecture. In his book L'Eau et les rêves, Gaston Bacherlard explores water symbolism through what he calls material imagination : "direct images from the matter" ${ }^{[10]}$. These recurrent images in the important literary corpus evoked in his book form the body of reminiscences to which the "formants" should refer.

Density, which separates superficial poetry from profound poetry, is distinguished between the sensitive values of the art work - attributable to translation - and the sensual values of the art work - attributable to correspondence -, the latter providing a more refined and powerful image. The reverie is therefore deeper when it comes to matter than when it comes to form. This is what motivates Gaston Bachelard to restore "the individualizing power of matter" ${ }^{\text {" } 19]}$, often forgotten in aesthetic science which, in his time, focused too much on the notion of form. He develops, through hermeneutics of North-Western literature and poetry, a water psychoanalysis. 
This whole design-driven research covers themes addressing the following symbols: the purity of clear water - a sacred purity -, the passage of time - the way of death -, the strongest composition of elements - water and fire -, the maternal evocations of water - in its actions - and the heavy water - the dark oppression it weighs. For the purpose of this article, two material images are presented. They both expose the oppositions of death and life images of water - which respectively refer to two chapter of L'Eau et les rêves: "le complexe de Caron"' and "L'eau maternelle et l'eau féminine"4.

\section{The crossover of two methods}

As mentionned earlier, the present work comprises two sections. First, the case study allows us to explore some ambiantal "formants". Following this, the architectural design project explores the notion of intent in the creation of an emotional architecture and the notion of "formant" as a scenographic mechanism to achieve it.

The case study proposes an analysis of the five atmospheres "mises en scenes" by Peter Zumthor inside the thermal facilities of Vals. The analysis uses a philosophical work presenting a psychoanalysis of an important corpus of literary and poetic works which highlight different material images of water. In L'Eau et les rêves, Gaston Bachelard shows "that certain matters - in particular water - transport in us their oneiric power, a kind of poetic strength that gives a unity to real poems." ${ }^{[20]}$ In other words, he demonstrates the coherence of the oneiric symbols offered by water in different aspects, as material images appear in a wide spectrum of works in north-western literature and poetry, going back to ancient Greece and stopping in the first half of the 20th century. The perception is no longer individual. It comes rather from the literary corpus studied by Bachelard, which demonstrates the inter-individuality in the analysis of the different "mise en scène" of atmospheres. It must be understood that the "formants" revealed below result from the ambiances perceived by the book, which brings us, of its own free will, its own experience in a narrative form.

The formants thus revealed under the bachelardian scope are then renewed in an architectural creation project leading to the completion of an original projectual process. The project is expressed in the form of five pavilions distributed along a $40 \mathrm{~km}$ path which is part of the old General Wade military road in Scotland. This section of the road links two little town in the south of the Highlands: Fort Augustus and Laggan. Linking the sensitive experience of space to the one of tasting scotch whiskey, the project explores the aesthetic relationships to water represented in different forms, concrete or abstract, within an architectural space. The program and the site chosen for the project promote the aesthetic experience by focusing on contemplation and hedonism. Each of the pavilions serves to enhance a flavour and aroma of the scotch whiskey realm. In order, along the path, the presented flavors are: woody, smoky, floral/fruity, peaty and iodized. The two pavilions presented below start and end the journey: the woody and iodized ones.

\section{From the case to the project}

The present section exposes the design objectives as an extension of the above theoretical framework. It presents the analysis of two atmospheres "mises en scène" in two rooms of the Vals' thermal baths, which led to the respective identification of two "formants", themselves reinterpreted in the ambiantal scenography of the woody and iodized pavilions. In other words, the analysis is divided in two cases, each one presenting the complete process, from

\footnotetext{
${ }^{3}$ Chapter titles translated by the author: Charon's complex

${ }^{4}$ Chapter titles translated by the author: Maternal water and feminine water
} 
the analysis itself to the creation of the pavilion. Those subsections present the following sequence of descriptions: the Vals' room' scenography; the perception from Bachelard's book; the atmosphere intended in the projected pavilion; and the expression of the "formant" reinterpreted in it.

\subsection{The mark of time}

In the baths' den, while five changing rooms follow one another on the left, a narrow lowering in the floor runs along the right wall and attracts the attention. Clear water flows through it, producing a light sound. This water which accompanies this first aesthetic experience guides the procession to the end of the corridor, from one door to the other. By looking up, one witnesses the source of this water. Synchronized with the rhythm of the changing rooms, five elementary gargoyles let out a continuous stream of water. Directly from the natural spring in Vals, the water marks the concrete with a layer of minerals that continues to thicken and widen over time.

For Gaston Bachelard, the poetic image linked to Charon's complex is hereby offered by the scenography of the stream of water and the trace that marks the passage of time. This trace, present long before the experiment described here, will also be present long after. While the aesthetic experience that is made of it is, all in all, ephemeral, the architecture that makes it possible is much more perennial. This controlled time mark underlines the difference in temporality scale between one's experience and what causes it. The patina, a testimony to this temporal gap, forces an awareness of the ephemeral reality of human life. Indeed, this first presence of water in the baths reminisces of a departure on water, which refers to the symbol of the never made journey, a symbol endorsed by the character of the ferryman, himself carrying a symbolic baggage allowing death to keep its sense of travel. This is how the formant of the ambiance is presented, referring the perceiving mind to the Charon complex. It is both the scenographic element that makes it possible to perceive the atmosphere and the sensitive result that imposes an awareness of death as a human condition.

The woody pavilion echoes this material image of the Charon's complex by using the patina. In order to give a plural meaning to this reverie and thus offer more opportunities for the visitor's reminiscence, the oneiric image poduced by the patina is used on different materials and over different time scales. Surrounded by a tightly rhythmic square colonnade, the upper floor is completely open to the outside. The tasting area is organized in two boxes on either side of the stairwell. Thin oak sections very close together at the perimeter of these boxes separate the tasting area from the rest of the pavilion. These two doorless rooms invite visitors to discover the woody flavour of Scotch whiskey (figure 1).

The choice of materials and their size in the tasting rooms (figure 2) results from this reflection based on the Charon's complex. From the most durable to the most ephemeral, stone, copper and oak each respect a temporal scale intelligible by the patina they present. In opposition on this scale, stone and oak define the main spaces. Copper, used in the roof and for the staircase, is mainly used to "mettre en scène" the patina. 


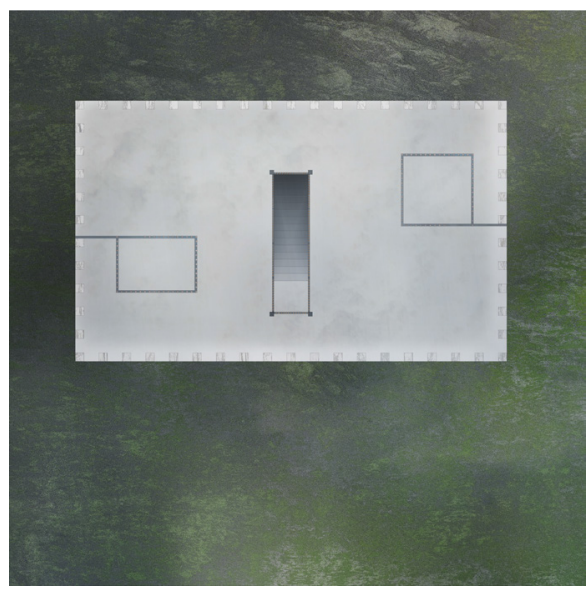

Fig. 1. Woody pavilion: $2^{\text {nd }}$ floor plan

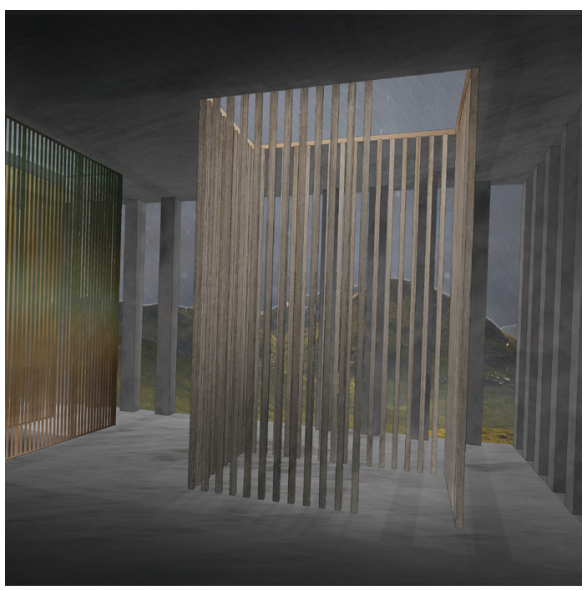

Fig. 2. Woody pavillion: interior perspective

\subsection{Of water and other first liquids}

In the heart of one of the stone monoliths that structure the space of Vals' installations, a particular smell attracts the attention. As one goes down into the pool, the smell is revealed. A small amount of essential oil gives the water a delicate aroma and texture. The basin contains thousands of yellow petals suspended in a cloudy, milky-looking water. The slight movement on its surface, combined with the essential oil mixed in, adds a cloudy appearance and a thick texture to the water, which is reminiscent of the appearance and texture of milk. Sitting on a submerged bench, the body floats between two waters. The perception of the body immersed and floating in complete safety refers to a level of comfort similar to the prenatal existence of the being. This sensation is here amplified by all the petals suspended in the basin. The scenography thus designed by Peter Zumthor helps to generate the maternal reverie of the petal basin.

In this basin, the water reveals its feminine character. Water is presented here as maternal, in its appearance as well as in its action. First, it diffuses a milky image through its slightly cloudy and thickened texture. As "all liquids are water"[21], the oneiric milk contained in the basin is reminiscent of filial love. Warm and thick, it envelops and cradles the body within it. Now the oneiric quality of water extends into the action. The experience of bathing, in this narrow and intimate room, connects the cradled body to the reverie of the prenatal bathing experience.

The iodized pavilion takes on this binary material image surrounding the reverie of maternal water - the appearance and the action. The oval-shaped pavilion floats in the center of a small lake along General Wade's road. Upon entry, the door closes behind, activating the light in a narrow space between two walls - the inner one being a scaled down copy of the outer one. In the heart of the inner wall is the tasting room. It is a brightly lit space but from which the light source remains a mystery (figure 3). 
The ovoidal shape, in addition to referring directly to an egg, eliminates the edges while offering a relatively flat floor, therefore stable on water (figure 4). It is first of all this loss of visual limit, inside the tasting room, that evokes the image of the sea. It is filial love, the first love, that is the most similar to that of the sea: to love the infinite character of the sea "is to give a material meaning, an objective meaning to the infinity of love for a mother." ${ }^{[10]}$ This characteristic of infinite water, specific to the sea, is coupled with its nourishing image. As an inexhaustible source of food, the sea plays a maternal role: it ensures a perennial abundance of food. In addition to these two reminiscences of filial love, which give the atmosphere of the pavilion a maternal character, the cradling action of the lake is also present. This action, an inherent quality of the matter, relaxes, rests and reassures. The rocking action is significant of the maternal reverie of water.

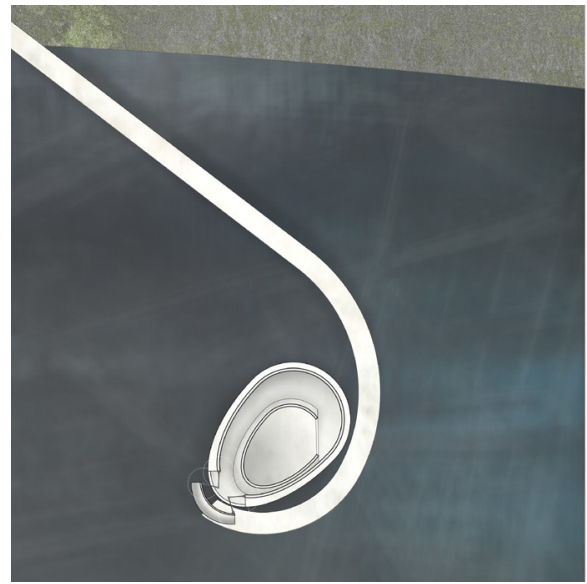

Fig. 3. Iodized pavilion: floor plan

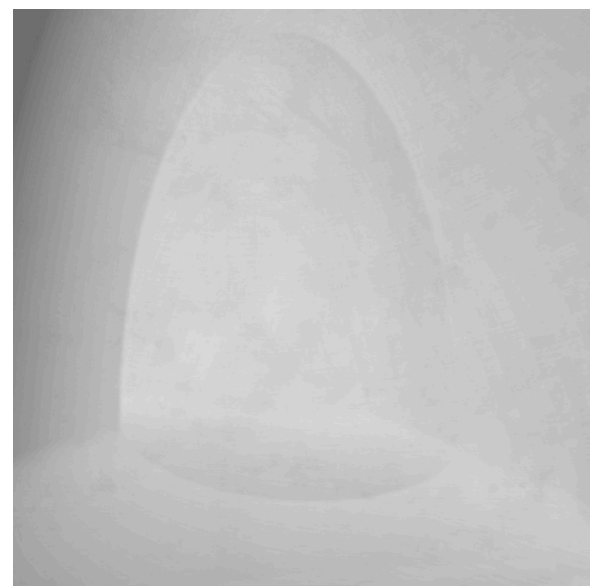

Fig. 3. Iodized pavillion: interior perspective

\section{Retrospection}

As a work of art, the architectural object conveys a sensitizing aesthetic, becoming a generator of emotions, themselves "a subjective translation of the ambiance of a place in its material as well as symbolic aspects" [11]. The method of reading the ambiances used in this design-driven research reveals a certain amount of objectivity to a northwestern literary context leading to the identification of "formants" of the sensitive ambiance. It also proposes a reappropriation of these "formants" by the "mise en scène" of a voluntarily emotional architecture.

In an interview with Mari Lending ${ }^{[12]}$, Peter Zumthor explains the link between the memory of a place and the emotion that architecture can evoke. The loop is closed, the reminiscence is the key to the thesis. By its scope, the corpus explored by Bachelard contains an important collective memory to which everyone can refer. Whether direct or indirect, knowledge of this literary oneiric references refers to the same material image of water. Reminiscence refers to the collective memory giving access to the reading keys of common sensitive ambiances which lead to an architecture that touches a wide range of visitors.

Although they were as deep and meaningful, other symbols presented in the book were not applied in this design-driven research because they couldn't be linked to Zumthor's Vals' project. These symbols could be used and applied to some further analysis of other atmospheres. 


\section{References}

[1] A. Berleant. "Aesthetic Sensibility." Ambiances Enjeux - Arguments - Positions(2015). Published electronically 30 mars 2015. http://ambiances.revues.org/526 ; DOI : 10.4000/ambiances.526.

[2] S. Schürger. "L'esthétique Du Paysage - Observer Et Créer Des Ambiances." Paper presented at the 1st International Congress on Ambiances, Grenoble 2008, Grenoble, France, (2008-09-10 2008).

[3] P. Ardenne, B. Polla, J.L. Genard, J. Le Maire, N. Gilsoul, P. Aebischer, L. Geninasca, et al. Architecture Émotionnelle : Matière À Penser. [in Français] [Lormont] : Le Bord de l'eau, (2011). [4]Wolberg, Nathalie. 2008. "Texture d'espaces - Territoires d'emotion : L'architecture comme objet intime." 1st International Congress on Ambiances, Grenoble 2008, Grenoble, France, 200809-10.

[5] P. Amphoux, J.P. Thibaud and G. Chelkoff. Ambiances En Débats. A la croisée, (2004).

[6] G. Chelkoff. "L'ambiance Sensible À L'architecture : Paradoxes Et Empathies Contemporaines." Paper presented at the Ambiances in action / Ambiances en acte(s) International Congress on Ambiances, Montreal 2012, Montreal, Canada, (2012-09-19 2012).

[7] G. Böhme. "Un Paradigme Pour Une Esthétique Des Ambiances : L'art De La Scénographie." Paper presented at the 1st International Congress on Ambiances, Grenoble 2008, Grenoble, France, (2008-09-10 2008).

[8] N. Gilsoul. "Jardiner L'architecture Émotionnelle - L'empirisme Comme Méthode Projectuelle De Luis Barragán." (2008). Published electronically 28-12-2008. http://www.projetsdepaysage.fr/fr/jardiner_1_architecture_emotionnelle.

[9] T. Ouard. "Essai Sur Le «faire Une Ambiance » En Architecture." Paper presented at the faire une ambiance creating an atmosphere, Grenoble, France, (2008-09-10 2008).

[10] G. Bachelard. L'Eau Et Les Rêves : Essai Sur L'imagination De La Matière. [in Français] Paris: J. Corti, (2005). 1942.

[11] N. Audas. "Le Rôle De L'affect Dans L'ambiance Ressentie." Paper presented at the 1st International Congress on Ambiances, Grenoble 2008, Grenoble, France, (2008-09-10 2008).

[12] P. Zumthor, H. Binet and M. Lending. A Feeling of History. Scheidegger \& Spiess, (2018) 